Indonesian Journal of Biotechnology, December, 2013

Vol. 18, No. 2, pp.151-160

\title{
Purification and Characterization of Protease From Bacillus sp. TBRSN- 1
}

\author{
Sebastian Margino ${ }^{1}$, Jumi' $^{\prime}$ ati $^{2}$, Ngadiman $^{2}$
}

\author{
${ }^{2}$ Biotechnology Postgraduate School, Universitas Gadjah Mada \\ ${ }^{1}$ Department of Agricultural Microbiology, Faculty of Agriculture, Universitas Gadjah Mada, Yogyakarta, \\ Indonesia
}

\begin{abstract}
Potato Cyst Nematode (PCN), Globodera rostochiensis, is one of the important potato's pests and caused economic looses up to 70\% in the several centrals of potato plantations in Indonesia. PCN's shell component of egg shell containing chitin (inner layer) and viteline/ protein (outer layer). The purpose of this research was to purify of protease Bacillus sp. TBRSN-1, isolate from tomato's rhizosfer in Yogyakarta province. The purified protease could be used for cutting the life cycle of PCN. Results showed that Bacillus sp. TBRSN-1 could produce extracellular protease and purification using DEAE-cellulose ion-exchange chromatography and Sephacryl S-300 gel filtration chromatography resulted in specific activity 4.31 fold and $1.68 \%$ recovery. Analysing using SDS-PAGE $12.5 \%$ and molecular weight $48.1 \mathrm{kDa}$. Km and Vmax values of the protease for casein substrate were $7.83 \mathrm{mg} / \mathrm{ml}$ and $4.03 \mu \mathrm{g} / \mathrm{h}$, respectively. The optimum activity at the temperature $30^{\circ} \mathrm{C}$ and $\mathrm{pH} 7.0$.
\end{abstract}

Keywords : protease, purification, indigenous Bacillus sp. TBRSN-1

\section{Introduction}

Plant-parasitic nematodes cause serious losses to a variety of agricultural crops worldwide. Since the traditional methods based on the use of nematicides and antihelminthic drugs are associated with major environmental and health concerns, the development of biocontrol agents to control nematodes is of major importance (Duncon, 1991). The potato cyst nematode Globodera rostochiensis is the major pests for the potato cultivars in several countries in the world (Margino et al., 2009). Soil treatment with nematocides for controlling Globodera, it is very expensive for farming community. In recent years biological control agents such as chitinolytic and proteolytic bacteria, fungi, actinomycetes were applied to control potato cyst nematode (PCN) eggs shell, for cutting

\section{*Corresponding author :}

Sebastian Margino

Department of Agricultural Microbiology, Faculty of Agriculture, Universitas Gadjah Mada, Yogyakarta, Indonesia their life cycle. Previous research succeded in controlling PCN up to $60 \%$ using mixed cultures inoculum (Margino et al., 2009) and succeded in purifying chitinases of selected bacteria and actinomycetes (Margino et al., 2010, Margino et al., 2012). Because of the fast breeding, easy cultivation and production compared to fungi, nematophagous bacteria have been used extensively as bioinsecticides against nematodes in soil, and levels of control equivalent to those of chemical pesticides development (Zhou et al., 2002). Egg cell of PCN containing vitelin (protein) and chitin layers so that protease can be used for controlling PCN through the namatode's egg.

Proteolytic enzymes are ubiquitous in occurrence, being found in all living organisms, and are essential for cell growth and differentiation. The extracellular proteases are commercial value and find multiple applications for example in biological control (bionematicide). Although there are many microbial sources are available for producing proteases, only a few are 
recognized as commercial producers, that is strains of Bacillus sp. (Gupta et al., 2002b). In this work, we present the purification and characterization protease of Bacillus sp. TBRSN-1, isolated from tomato's rhizosfer.

\section{Material And Methods Microorganism and inoculum preparation}

A culture of Bacillus sp. TBRSN-1 previously isolated from soil and identified by standard method for bacterial identification. Stock cultures were maintained in nutrient broth medium (Difco) with 70\% glycerol, cultures were preserved at $-20^{\circ} \mathrm{C}$. One loopful of bacteria strain (Bacillus sp. TBRSN-1) was transferred to a tube of sterile containing of nutrient broth and allowed to grow overnight at $37^{\circ} \mathrm{C}$ (Shafee et al., 2005; Sharmin et al., 2005) before being used to inoculation.

\section{Protease activity}

The protease enzyme activity was determined as previously mentioned by Secades and Guijarro (1999) using casein as a substrate. Briefly, $120 \mu \mathrm{L}$ of a suitable dilution of enzyme solution was added to 480 $\mu \mathrm{L}$ of casein $(2 \% \mathrm{wt} / \mathrm{vol})$ in reaction buffer, and the mixture was incubated at $30^{\circ} \mathrm{C}$ for 30 $\mathrm{min}$. The reaction was terminated by adding $600 \mu \mathrm{L}$ of $10 \%(\mathrm{v} / \mathrm{w})$ TCA and left for $30 \mathrm{~min}$ on ice, followed by centrifugation at 15,000 $x \mathrm{~g}$, at $4^{\circ} \mathrm{C}$ for $10 \mathrm{~min}$. Eight hundred $\mu \mathrm{L}$ of the supernatant was neutralized by adding $200 \mu \mathrm{L}$ of $1.8 \mathrm{~N} \mathrm{NaOH}$, and the OD value was measured using spectrophotometer at $420 \mathrm{~nm}\left(\lambda_{420}\right)$. One units of enzyme activity was defined as the amount of enzyme which required to produce an increase in OD value at $420 \mathrm{~nm}$ equal to $1.0 \mathrm{in} 30 \mathrm{~min}$, at $30^{\circ} \mathrm{C}$.

The protein content of protease was determined by the method of Lowry et al., (1951) as mentioned in Bradfort (1976) using bovine serum albumin as a standard and during the course of enzyme purification by measuring at OD value at $\lambda 280 \mathrm{~nm}$.

The specific activity of the protease protein was expressed in terms of units/ $\mathrm{mg}$ protein $/ \mathrm{ml}^{-1}$ according the following equation: Specific activity = enzyme activity / protein content $\left(\mathrm{mg} / \mathrm{ml}^{-1}\right)$.

\section{Protease production (Singh et al., 1999)}

Protease crude enzyme was produced by fermentation. Bacillus sp. TBRSN-1 was cultivated in minimal medium consisting of (g/l): $\mathrm{K}_{2} \mathrm{HPO}_{4} 0.7, \mathrm{KH}_{2} \mathrm{PO}_{4} 0.3, \mathrm{MgSO}_{4} .7 \mathrm{H}_{2} \mathrm{O}$ $0.5, \mathrm{FeSO}_{4} .7 \mathrm{H}_{2} \mathrm{O} 0.01, \mathrm{ZnSO}_{4} 0.001, \mathrm{MnCl}_{2}$ 0.001 , skim milk $1 \%$, and distilled water 1 $\mathrm{L}, \mathrm{pH}$ 7.0. Media were autoclaved at $121^{\circ} \mathrm{C}$ for $20 \mathrm{~min}$. Cultivations were performed on different condition (inoculum concentration, $\mathrm{pH}$, substrate (skim milk) concentration, agitation, temperature, and incubation period) in $250 \mathrm{ml}$ erlenmeyer flasks with a working volume of $20 \mathrm{ml}$. The cultures were centrifuged and the supernatants were used for estimation of proteolytic activity.

Optimization of growth conditions: Optimization was done under the inoculum concentration $(2.5,5.0,10$, and $15 \%(\mathrm{v} / \mathrm{v})$; different $\mathrm{pH}$ values $(50 \mathrm{ml}$ of selected medium of different $\mathrm{pH} 5.0,5.5,6.0,6.5,7.0$, 7.5 , and 8.0 respectively; different substrate (skim milk) concentrations $\left(\mathrm{g} / \mathrm{l}^{-1}\right)$ was performed using $0.5,1.0,2.0,3.0$ and $4.0 \%$ $(\mathrm{w} / \mathrm{v})$, then incubated $48 \mathrm{~h}$ at $30^{\circ} \mathrm{C}$; different agitation (150, 200, and $250 \mathrm{rpm})$; incubation temperature $\left(30^{\circ} \mathrm{C}\right.$ and $\left.37^{\circ} \mathrm{C}\right)$; The best results of these condition teatments were applaied to the fermentor for looking best conditions of aeration, desolved oxsygen, and time of proteasevproduction, during incubation for 96 hours.

\section{Purification of the protease}

The culture supernatant was first subjected toammonium sulphate precipitation (Scopes, 1994). Poteins presents in culture broth were extracted by ammonium suplhate $40 \%, 50 \%, 60 \%, 70 \%, 80 \%$, and $90 \%(\mathrm{w} / \mathrm{v})$. Extractants were collected by centrifugation at $10,000 \mathrm{~g}, 4^{\circ} \mathrm{C}$ for $45 \mathrm{~min}$, and the pellet was suspended in $20 \mathrm{mM}$ buffer phosphate, $\mathrm{pH7.0.}$ The $40 \%(\mathrm{w} / \mathrm{v})$ ammonium sulphte fraction was subjected to gel filtration on Sephacryl S- 300 column $(1.5 \times 60 \mathrm{~cm})$ equilibrated with 
$20 \mathrm{mM}$ Tris- $\mathrm{HCl}, \mathrm{pH} 8.0$ containing $0.2 \mathrm{M}$ $\mathrm{NaCl}$ and $0.02 \% \mathrm{NaN} 3$. Fractions of $1.5 \mathrm{ml}$ were collected at a flow rate of $46 \mathrm{ml} / \mathrm{h}$ with the same buffer. Protein content and protease activity were determined. All purification steps were conducted at temperatures not exceeding $4^{\circ} \mathrm{C}$.

Polyacrylamide gel electrophoresis (Laemmli, 1970)

Sodium Dodecyl Sulfate-PolyAcrylamide Gel Electrophoresis (SDS-PAGE) was carried out for the determination of purity and molecular weight of the enzyme as described by Laemmli (1970) using a 5\% $(\mathrm{w} / \mathrm{v})$ stacking gel and $10 \%(\mathrm{w} / \mathrm{v})$ separating gel. The molecular weight of the enzyme was estimated using a low molecular weight calibration kit as markers consisting of: phosphorylase b (97 kDa), bovine serum albumin (66 kDa), chicken egg ovalbumin (45 kDa), bovine carbonic anhydrase (29 $\mathrm{kDa})$, and bovine a-lactalbumin (14.2 kDa). Protein bands were visualized by staining with Coomassie Brilliant blue $0.25 \%$ (w/v) and nitrate silver $0.1 \%(\mathrm{w} / \mathrm{v})$.

\section{pH optimum and $p H$ stability (Harman et al., 1993)}

The optimum $\mathrm{pH}$ of the purified protease was studied over a $\mathrm{pH}$ of $3.0,3.5,4.0,4.5$, $5.0,5.5,6.0,6.5,7.0,7.5,8.0,9.0$, and 10 with casein as a substrate. For the measurement of $\mathrm{pH}$ stability, the enzyme was incubated for $30 \mathrm{~min}$ at $30^{\circ} \mathrm{C}$ in different $\mathrm{pH}$ buffers and the residual proteolityc activity was determined under standard assay conditions. The following buffer system were used: 100 $\mathrm{mM}$ phosphate buffer, $\mathrm{pH}$ 6.0-7.5; $100 \mathrm{mM}$ Tris-HCl buffer, $\mathrm{pH}$ 8.0-8.5; and $100 \mathrm{mM}$ glycine-NaOH buffer, pH 9.0-12.

\section{Temperature effect on protease activity and stability}

To investigate the effect of temperature, the activity was measured using casein as a substrate at the temperature range from $10^{\circ} \mathrm{C}$ to $50^{\circ} \mathrm{C}$ in $100 \mathrm{mM}$ phosphate buffer,
$\mathrm{pH}$ 7.0. Thermal stability was examined by incubating the purified enzyme at different temperatures. Aliquots were withdrawn at desired time intervals to test the remaining activity at $\mathrm{pH} 7.0$ and $30^{\circ} \mathrm{C}$. The non-heated enzyme was considered as control (100\%).

\section{Enzyme kinetics determination}

$\mathrm{K}_{\mathrm{m}}$ and $\mathrm{V}_{\max }$ were determined by the kinetics of Michaelis-Menten Model reactions as described by Wilson and Walker (2005).

\section{Result And Discussion \\ Production of protease and precipitation using ammonium sulphate}

Bacillus sp. TBRSN-1 was originally isolated from soil around rhizosphere of tomato plant in (Sleman, Yogyakarta) and had high protease and chitinase activities in the culture broth medium. This isolate was also one of the mixed cultures inoculum candidate of bionematicides (data Margino et al., 2009). Production of extracellular protease by new strain Bacillus sp. TBRSN-1 was done in the two liter fermentor, based on the optimization of growth conditions $(5 \%$, $\mathrm{v} / \mathrm{v}$ ) of inoculums, substrate concentration $(1 \%, \mathrm{w} / \mathrm{v}), \mathrm{pH}$ value 7 , agitation $150 \mathrm{rpm}$, temperature at $30^{\circ} \mathrm{C}$, and incubation time 60 hours.

\section{Enzyme precipitation and purification}

Present tproteins in the culture filtrate were extracted by ammonium sulfate 40, 50, $60,70,80$, and $90 \%(\mathrm{w} / \mathrm{v})$. Result showed that $40 \%$ saturation was able to produce a maximum protease activity, $324.13 \mathrm{U} / \mathrm{mg}$, and followed $277 \mathrm{U} / \mathrm{mg}$ for saturation $50 \%$ (w/v) (Figure 1). Furthermore, ammonium sulphate in this $40 \%$ saturation level was used for precipitating protein in crude enzyme. The added ammonium sulphate will press out of water molecule from protein and cause the hydrophobic condition of protein compounds (Harris and Angal, 1990). In addition to, ammonium sulphate also leads to the protein precipitation and reduces its solubility. While the solubility 
of protein decrease, interaction between hydrophobic regions formed agregates, then agregates of proteins which contained of big molecules suddenly precipitated and resulted in more precipitates until its optimum concentration, Figure 1 (Scope, 1994). Ammonium sulphate purification increased the protease activity 1.46 fold. The precipitation step also decreased the overall protein concentration compared to the protein in the crude enzyme. Icreasesing of the Bacillus sp. TBRSN-1 protease activity using ammonium precipitation 1.46 fold are consistent with published literature, which shows a purification (fold) up to 9,6 (Liao et al., 1998). The prcipitation also gave lower result compared to precipitation of protease Burkholderia strain $2.2 \mathrm{~N}$, using ammonium sulphate $40-60 \%(\mathrm{w} / \mathrm{v})$ produce protease activity 20 fold (Jewell, 2000). A little bit different result showed by protease activity from Bacillus sp. PS719 which precipitated using ammonium sulphate $80 \%$, resulted in 1.5 fold (Towatana et al., 1999).

The results of ammonium sulphate precipitation in saturation level $40 \%(\mathrm{w} / \mathrm{v})$ as much as one $\mathrm{ml}$ (formerly been dialyzed with 0.05 PBS pH 7.0) applied into the colomn ion exchange chromatography containing DEAE Cellulostein. The 100 fractions were measured in early experiment to find out protein concentration of each fractions (based

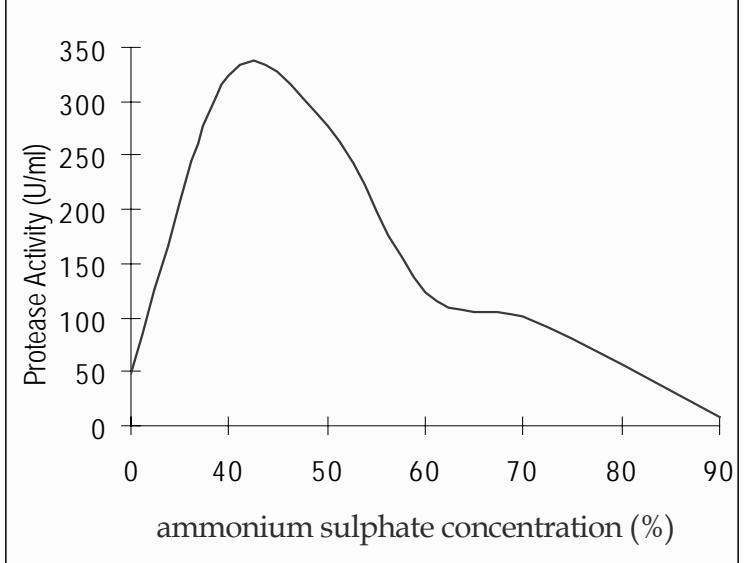

Figure 1. Different effect of ammonium sulphate concentration on purifying protease protein of Bacillus sp. TBRSN-1

on the absorpton value at $280 \mathrm{~nm}$ ). Results showed that two peak of protein but only one had protease activity, that fraction numbers 7-14 and 15-25. After collecting the samples and then be run using SDS-PAGE was found out two lines with a little bit far of their distance (data unshown). Furthermore analysis was done using gel filtration chromatography method by SephacrylS-300 (Figure3). This experiment has measured 70 fractions to find out the protein contents of each fraction (based on absorption value at $280 \mathrm{~nm}$ ). In the gel filtration, one protein peak was observed, which formed by fraction number 51 , but fraction numbers 50 and 52 have closed protein peaks and they

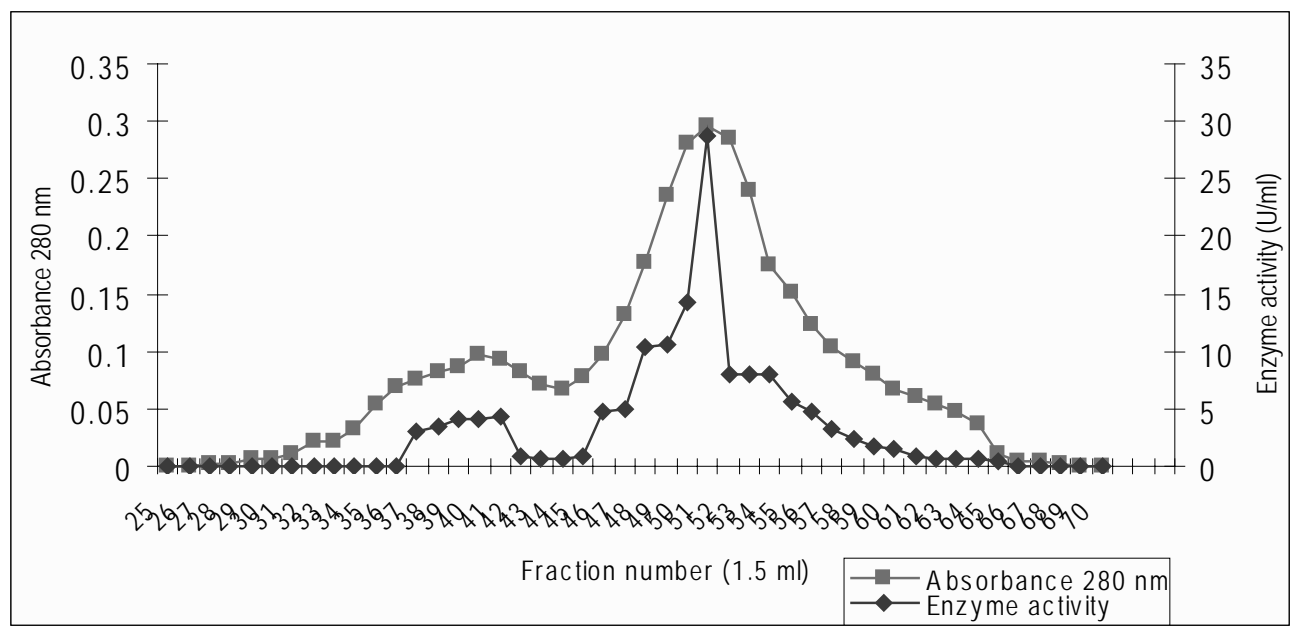

Figure 3. Elution profile of protease purification with gel filtration on Sephacryl S-300 
Table 1. Summary of the purification of Bacillus $s p$. TBRSN-1 protease

\begin{tabular}{lccccc}
\hline & $\begin{array}{c}\text { Total Protein } \\
(\mathrm{mg})\end{array}$ & $\begin{array}{c}\text { Total activity } \\
\left(10^{3} \mathrm{U}\right)\end{array}$ & $\begin{array}{c}\text { Specific activity } \\
\left(10^{3} \mathrm{U} / \mathrm{mg}\right)\end{array}$ & $\begin{array}{c}\text { Purification } \\
(\text { fold })\end{array}$ & $\begin{array}{c}\text { Recovery } \\
(\%)\end{array}$ \\
\hline Crude enzyme & 116.45 & 24761.90 & 212.64 & 1.00 & 100.00 \\
40\% ammonium sulfate fraction and & 38.37 & 11901.67 & 310.16 & 1.46 & 48.06 \\
dialysis & & & & & \\
DEAE Cellulose & 0.82 & 533.33 & 653.60 & 3.07 & 2.15 \\
Sephacryl S-300 & 0.45 & 416.67 & 916.76 & 4.31 & 1.68 \\
\hline
\end{tabular}

had high protease activities. Futhermore, the samples were collected into one tube, then to be freezed-dried for characterization of enzyme. Enzyme purification using Sephacryl S-300 may increased enzyme purity as much as 4.31 times. The yield and purity for each purification steps were summarized at Table 1.

The protease purification using DEAECellulose at Table 1, showed 3.07 fold compared to crude enzyme, its specific activity $653.60 \mathrm{U} / \mathrm{mg}$ protein, and its recovery was $2.15 \%$. This result a little bit different with purification of extracellular protease from Bacillus subtilis EAG-2, using DEAE-Cellulose, the overal recovery $29 \%$ and the purity level was 11 fold (Ghafoor and Hasnain, 2010). The extracellular protease was purified on Sephacryl-300 had purification value 4.3-fold with a recovery $1.68 \%$ and a specific activity $916.76 \mathrm{U} / \mathrm{mg}$ of protein.

All operations were carried out $4^{\circ} \mathrm{C}$. Only $40 \%$ ammonium sulphate was subjected to gel filtration on Sephacryl S-300.

\section{Characterization of protease}

The characterization of protease were done including SDS-PAGE analysis, molecu;lar weight, $\mathrm{pH}$ value and temperature effect.

The character of protease protein produced by Bacillus sp. TBRSN-1 could be

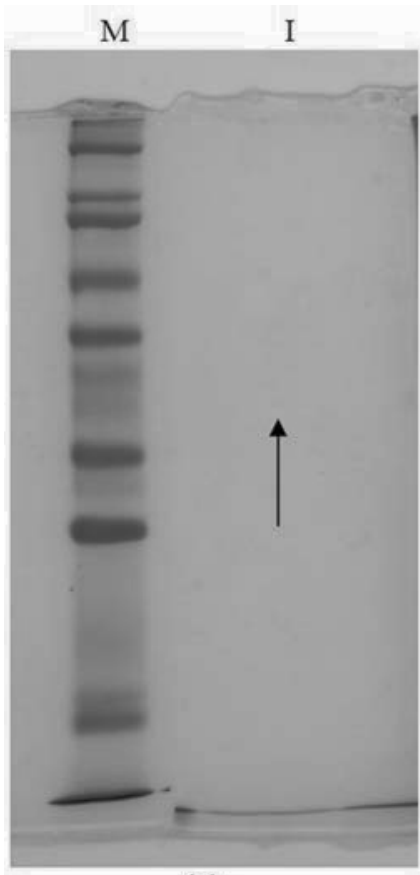

(a)

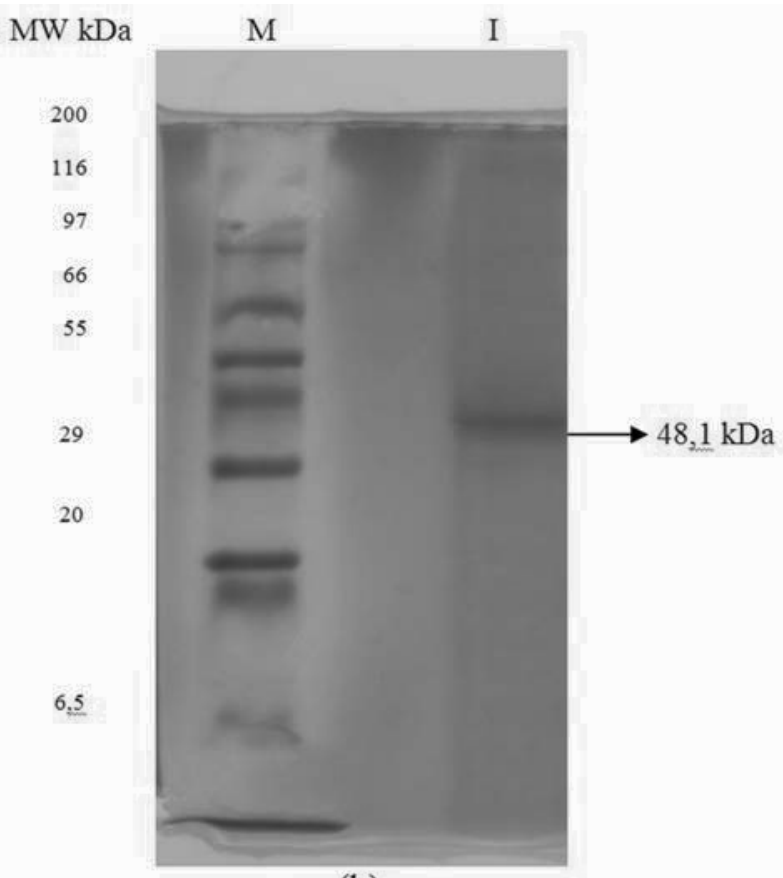

(b)

Figure 4. SDS-PAGE of the purified protease from Bacillus sp. TBRSN-1. (a) Staining with coomassie brilliant blue $0.25 \%(\mathrm{w} / \mathrm{v})$; (b) Staining with nitrate silver $0.1 \%(\mathrm{w} / \mathrm{v}) . \mathrm{M}=$ Markers; $\mathrm{I}=$ purified protease. 


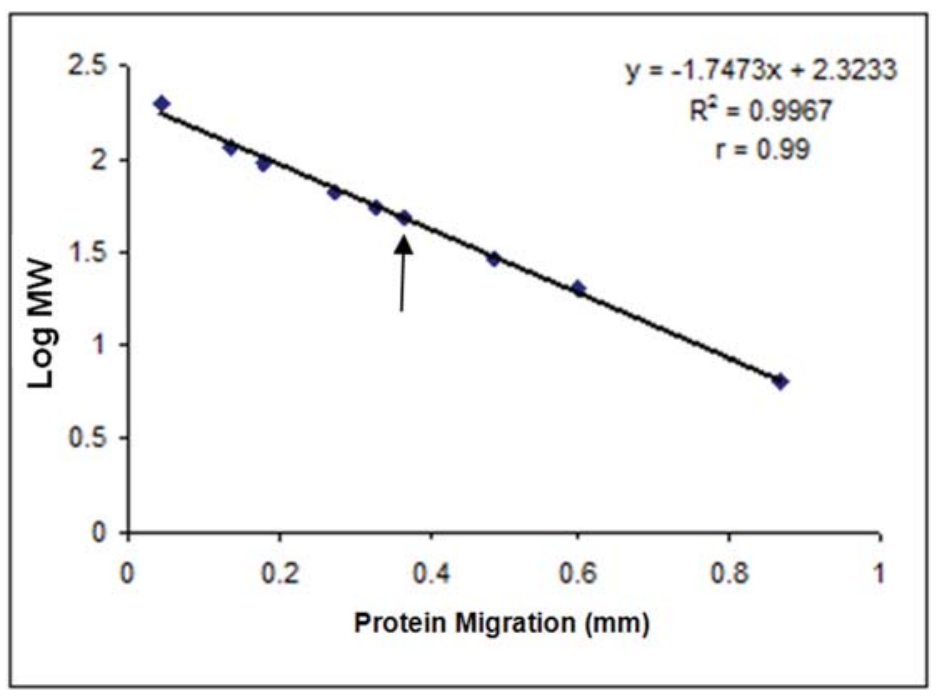

Figure 5. Determination of molecular weight of protease at $\mathrm{pH}$ optimum

performed on 10\% SDS-PAGE (Figure 4). This figure showed that one band of protease protein was found in this experiment. The molecular weight of single protein that resulted in Sephacryl S-300 isolation was determined using relative mobility calibration curve of standard polypeptide (Figure 5). The molecular weight estimation was determined using regression equation $\mathrm{Y}=2.3235-1.7473 \mathrm{X}$ (with $\mathrm{r}=0.99$ ), Figure 5 .

The purified protease was homogenous on SDS-PAGE and its molecular weight was estimated to be $48.1 \mathrm{kDa}$ (Figure 4).

The estimation of protease molecular weight of Bacillus sp.TBRSN-1was about 48,1 $\mathrm{kDa}$ (Figure 5). It was supposed that this band is protease, this was approved by increasing of protease activity and its enzyme purity. Padmapriya and Williams (2012) reported that the purified neutral protease of Bacillus subtilis had molecular weight $50 \mathrm{kDa}$, while purified serine protease from Bacillus sp. from marine had molecular weight $37 \mathrm{kDa}$ (Padmapriya et al., 2012). Towatana et al. (1999) reported that purified an extracellular protease from alkalophilic thermophile Bacillus sp. PS 719 using DEAE-Cellulose ion-exchange chromatography had molecular weight 42 $\mathrm{kDa}$. Yang et al. (2000) reported that Bacillus subtilis isolated from soil in Taiwan, which purified using DEAE-Sepharose ion-exchange chromatography and Sephacryl S-200 gelpermeation chromatography showed that protease had molecular weight $44 \mathrm{kDa}$.

Based on the several of researches showed that molecular weight of protease from Bacillus sp. TBRSN-1 had the similar types of them.

\section{Effect of pH on enzyme activity}

The $\mathrm{pH}$ profile of the purified enzyme was determined using different buffers of varying $\mathrm{pH}$ values. The purified enzyme was active in the $\mathrm{pH}$ range $3.5-9.0$, with an optimum activity at pH 7.0 (Fig. 6a) with protease activity was $24.58 \mathrm{U} / \mathrm{ml}$. Similarly, Abdul-Rouf (1990) reported that the optimum $\mathrm{pH}$ for all purified 4 proteases enzymes in their reaction mixture was found to be 7.2. Purified protease of Bacillus sp. isolated from soil samples around the Bungalore had specific activity at $\mathrm{pH}$ neutral (Josephine et al., 2012), other purified protease of Bacillus subtilis also had activity at $\mathrm{pH} 7.0$ (Padmapriya and Williams, 2012).

\section{Effect of temperature on the enzyme activity}

The effect of temperature on the activity of protease enzyme was examined at various 

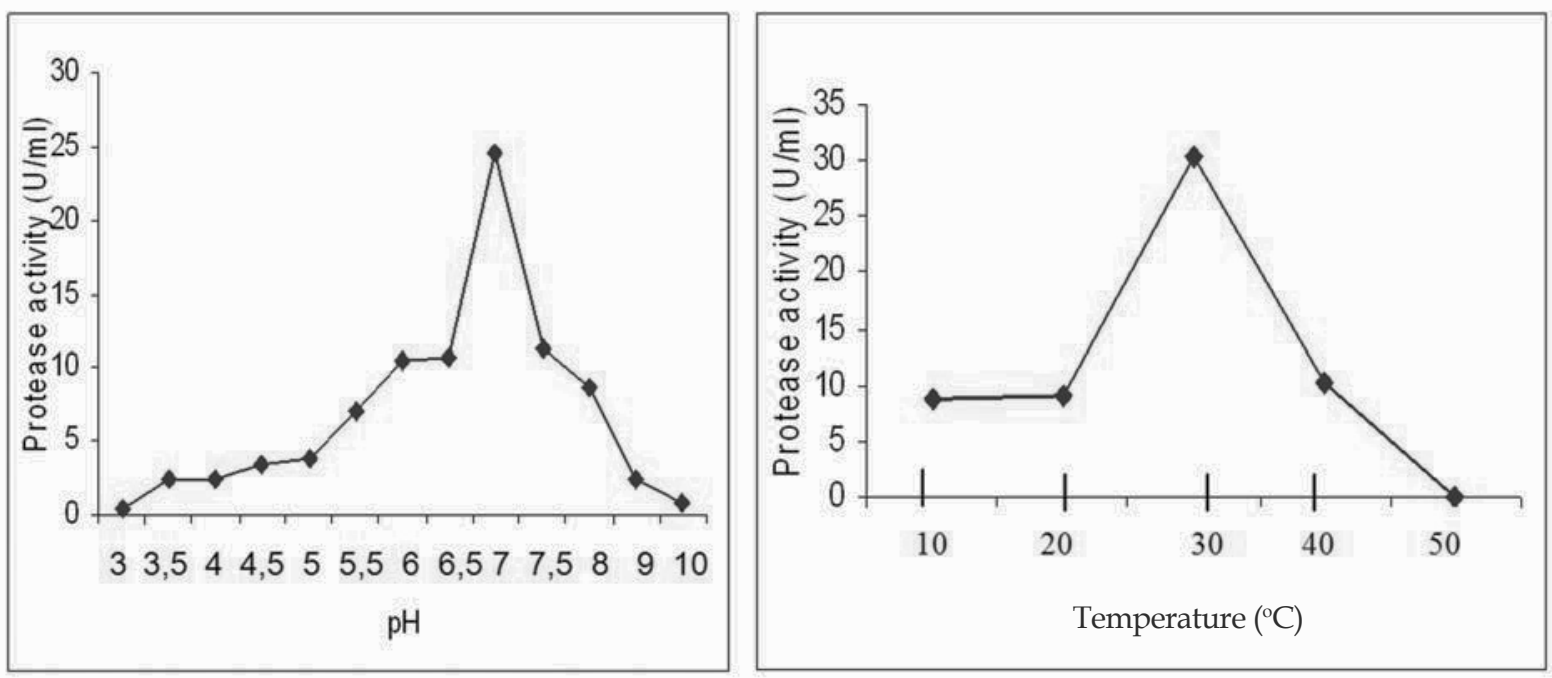

Figure 6. (a) Effect of $\mathrm{pH}$ on the activity of the purified protease; (b) Effect of temperature on the activity of the purified protease from Bacillus sp. TBRSN-1.

temperatures. The purified protease was active between $10^{\circ} \mathrm{C}$ to $40^{\circ} \mathrm{C}$, with an optimum around $30^{\circ} \mathrm{C}$ (protease activity $30.36 \mathrm{U} / \mathrm{ml}$ ) (Figure $6 \mathrm{~b}$ ). The protease activity at $10^{\circ} \mathrm{C}$ and $40^{\circ} \mathrm{C}$ were about $8.75 \mathrm{U} / \mathrm{ml}$ and $10.24 \mathrm{U} / \mathrm{ml}$, respectively. The enzyme was completely inactivated after $30 \mathrm{~min}$ incubation at $50^{\circ} \mathrm{C}$. While the temperature below or above $30^{\circ} \mathrm{C}$ exhibited lower activities of protease. Secades and Guijarro (1999) reported that a novel exoprotease, that was purified from the culture supernatant of Yersinia ruckeri (fish pathogen), had more activity in the range of 25 to $42^{\circ} \mathrm{C}$ and had an optimum condition at $37^{\circ} \mathrm{C}$. Asker et al. (2013) reported that protease of Bacillus megaterium had the optimum activity at $50^{\circ} \mathrm{C}$, while other purified protease from Bacillus subtilis had optimum activity at $37^{\circ} \mathrm{C}$. This illustration showed that optimum temperature of protease from several Bacillus sp. had the large variation.

\section{Determination of $K_{m}$ and $V_{\max }$ value of protease}

The result of enzyme kinetic analysis $\left(\mathrm{K}_{\mathrm{m}}\right.$ and $V_{\max }$ ) are shown in Table 2. Determination of $\mathrm{Km}$ and Vmax values were based on the $\mathrm{pH}$ condition and optimum temperature that have been procured. In this event, the increasing of substrate saturation will increase enzyme activity to achieve a certain limitations at the certain substrate saturation as well, so that the with the increasing of substrate after optimum limitations will not increase the enzyme activity.

Michaelis Menten's (Km) constant value analysis and maximum speed (Vmax) can be seen at Table 2. According to above computation, there was quantitative relation between the speed (Vi) with substrate saturation (S). Michaelis Menten's (Km) constant was procured about $7.83 \mathrm{mg} / \mathrm{ml}$ and maximum speed $\left(\mathrm{V}_{\max }\right)$ was $4.03 \mu \mathrm{g} / \mathrm{h}$ with regression equation; $Y=1942.7 X-248.29$ and have correlation value about $\mathrm{r}=0.998$. Wilson (2005) explained that enzyme activity more higher, if the its $\mathrm{K}_{\mathrm{m}}$ values was small. The correlation between of reaction velocity (v) with substrate concentration as shown at Figure 7.

\section{Conclusion}

The best conditions for protease production by Bacillus sp. TBRSN-1 were: substrate concentration (skim milk) 1.0\% $(\mathrm{w} / \mathrm{v})$, inoculum concentration $5.0 \%(\mathrm{v} / \mathrm{v})$, growth temperature $30^{\circ} \mathrm{C}, \mathrm{pH} 7.0$, agitation at $150 \mathrm{rpm}$, and incubation time for 60 hours.

Purification of Bacillus sp. TBRSN-1 protease using DEAE-Cellulose and Sephacryl 
Table 2. Data of $\mathrm{K}_{\mathrm{m}}$ and $\mathrm{V}_{\max }$ values of protease

\begin{tabular}{ccccrl}
\hline No & {$[\mathrm{S}]$} & $1 /[\mathrm{S}]$ & $\mathrm{Vi}$ & \multicolumn{1}{c}{$1 / \mathrm{Vi}$} & Regression equation \\
\hline 1. & 0,5 & 2,00 & 0,000280 & 3570,400 & $\mathrm{Y}=1942,7 \mathrm{X}-248,29$ \\
2. & 1,0 & 1,00 & 0,000530 & 1887,000 & $\mathrm{~K}_{\mathrm{m}}=7,83 \mathrm{mg} / \mathrm{ml}$ \\
3. & 1,5 & 0,67 & 0,000930 & 1075,500 & $\mathrm{~V}_{\max }=4,03 \mu \mathrm{\mu g} / \mathrm{h}$ \\
4. & 2,0 & 0,50 & 0,001739 & 575,000 & \\
\hline
\end{tabular}

[S] : Substrate concentration

$\mathrm{Vi}$ : reaction velocity

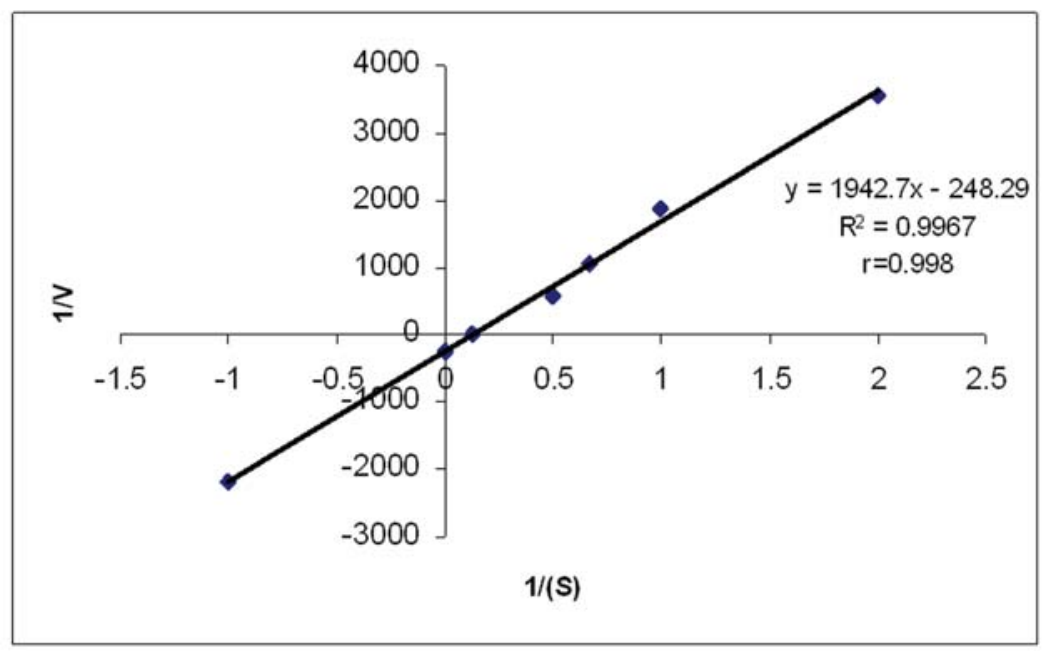

Figure 7. Lineweaver - Burk plot

S-300 gel filtration, increased a 4.31-fold in specific activity and $1.68 \%$ recovery. The molecular weight of the purified protease was estimated to be $48.1 \mathrm{kDa}$.

The optimum conditions of pure protease activity were on temperature $30^{\circ} \mathrm{C}$, $\mathrm{pH} 7.0, \mathrm{~K}_{\mathrm{m}}$ and $\mathrm{V}_{\max }$ values were $7.83 \mathrm{mg} /$ $\mathrm{ml}$ and $4.03 \mu \mathrm{g} / \mathrm{h}$, respectively.

\section{Acknowledgment}

This research was funded by The Ministry of Reseach and technology Republic of Indonesia under The Insentive Research Program, 2007-2009 of Prof. Sebastian Margino, Ph.D.

\section{References}

Abdul-Rouf U. M. 1990. Studies of proteolytic bacteria isolated from certain localities in Aswan city. A thesis (MSc.), Botany and Microbiology Department, Faculty of Science, Al-Azhar University, Cairo.
Ammar M. S., 1975. Studies on thermophilic bacteria. Ph.D., Thesis, Botany Department, Faculty Science, Al-Azhar University, Cairo, Egypt.

Anonymous, 2010. Control of potato cyst nematodes. Official control programma for sampled units recorded as infested. Guidance for growers and landowners. Science and Advise for Scottis Agriculture. The Scottish Goverment.

Asker, M.S., M.G. Mahmoud, K.E. Shebwy and M.S. Abd el Aziz., 2013. Purification and characterization of two thermostable protease fraction from Bacillus megaterium. J. of Gen. Engineer. and Biotechnol., (in press MMS. Asker etal., http:/ / dx.doi.org)

Bradford, M.M., 1976. A Rapid and Sensitive Method for Quantification of Microgram Quantities of Protein Utilizing the Principle of Protein-Dy Binding. Anal. Biochem., 72, 248-254 
Beg, Q.K., V. Sahai and R. Gupta, 2003. Statistical media optimization and alkaline protease production from Bacillus mojavensis in bioreactor. Process Biochem., 39, 203-209.

Darah, I. and C.O. Ibrahim, 1996. Effect of agitation on production of lignin degrading enzymes by Phanerochaete chrysosporium grown in shake-flask cultures. As. Pac. J. Mol. Biol. Biotechnol., 4, 174-182.

Duncon, L.W., 1991. Current Options for Nematode Management. Annu. Rev. Phytopathol., 29, 469-490.

El-Safey, E.M., U.M. Abdul-Raouf. (2004) Production, Purification and Characteriation of Protease Enzyme from Bacillus subtilis. Botany and Microbiolgy Departement, Faculty of Science, AlAzhar University, EGYPT.

Ghafoor, A. and S. Hasnain, 2010. Purification and characterization of an extracellular protease from Bacillus subtilis EAG-2 strain isolated from ornamental plant nursery. Polish J. of Microbiol., 59 (2), 107-112

Gupta, R., Beeg QK, Loranz P., 2002a. Bacterial alkaline proteases: molecular approaches and industrial applications. Appl. Microbiol. Biotechnol., 59 (1), 15-32.

Gupta, R., Beeq Q. K.; Khan S. And Chauhan, B., 2002b. An overview on fermentation, downstream processing and properties of microbial alkaline proteases. Appl. Microbiol. Biotechnol., 60 (4), 381-395.

Harris, E.L.V. and S. Anggal. (1990) Protein purification Method. Oxford University Press. New York.

Harman, G.E., C.K. Hayes, M. Lorito, R.M. Broadway, A. Di Pietro, C. Peterbauer and A. Tronsmo., 1993. Chitolytic enzymes of Trichoderma harzianum; Purification of Chitobiosidase and Endochitinase. Phytopathology, 83, 313-318

Jew11, S.N., 2000. Purification and characterization of a novel protease from Burkholderia strain 2.2N. Thesis Faculty of Virginia Polytechnic Institute and State University. Blacksburg, Virginia.
Josephine, F.S., V.S. Ramya, N. Devi, S.B Ganapa, K.G. Siddalingeshwara, N. Venugopal and T. Vishwanatha., 2012. Isolation, production and characterization of protease from Bacillus sp. isolated from soil sample. J. of Microbiol. and Biotechnol. Res., 2(1), 163-168

Kumar, C.G. and H. Takagi, 1999. Research review paper: microbial alkaline proteases: from a bioindustrial viewpoint. Biotechnol. Adv., 17, 561-94.

Kohlmann K. L.: Nielsen S. S; Stenson L.R and Ladisch M. R., 1991. Production of proteases by psychrotrophic microorganisms. J. Dairy Sci., 74, 3275-3283.

Laemmli, U.K., 1970. Cleavage of Structural Proteins during the assembly of the head of bacteriophage T4. Nature, 227, 680-685.

Liao, C.H. and D.E. McCallus., 1997. Biochemical and genetic characterization of an extracellular protease from Pseudomonas fluorescens CY091. Appl. Environ. Microbiol., 64, 914-921.

Lowry, O.H., N.J. Rosebrough, A.L.Farr, R.L. Randall., 1951. Protein Measurenment with the Folin Phenol Reagent. J. Biol. Chemis., 193: 265-273.

Margino, S., Mulyadi, T.K. Pronoand B. Rahayu. 2009. Report of Reseacrh Project. Biological control of potato cyst nemaodes (Globodera rostochiensis) integratedly. Ministry of Research and Technology. Indonesia.

Margino, S.,A. J. Nugroho and W. Asmara., 2010. Purification and characterization of Streptomyces sp. IK chitinase. Indonesian J. of Biotechnol, 15(1), 29-36

Margino, S., C. Behar and W. Asmara., 2012. Isolation and purification of chitinase Bacillus sp. D2 isolated from potato rhizosfer. Indonesian J. of Biotechnol., 17(1), 69-78

Padmapriya, M and C.Williams. 2012. Purification and characterization of Ization of neutral protease enzyme from Bacillus subtilis. J. Microbiol. Biotechnol. Res., 2(4), 612-618. 
Padmapriya, B., T. Rajeswari, R. Nandita and F. Raj., 2012. Production and purification of alkaline serine protease from marine Bacillus species and its application in detergent industry. European J. Appl. Sci., $4(1), 21-26$

Qadar,S.A.U.,E.Shireen, S.Iqbal, A.Anwar. 2009. Optimization of Protease Production from Newly Isolated Strain of Bacillus sp. PCSIR EA-3. Institute of Sustainable Halophite Utilization and Dept of Biochemistry University of Karachi, Pakistan.

Rahman RNZR, Basri M, Salleh AB., 2003. Thermostable alkaline protease from Bacillus stearothermophilus FI; nutritional factors affecting protease production. Ann Microbiol., 53, 199-210.

Rahman, R.N.Z.A., L.P. Geok, M. Basri, A.B. Salleh, 2005. Physical factors affecting the production of organic solvent-tolerant protease by Pseudomonas aeroginosa strain K. Biores. Technol., 96, 429-436.

Singh , J., R.M.Vohra and D.K. Sahoo., 1999. Alkaline protease from new obligate alkalophilic isolate of Bacillus sphaericus. Biochemical Engineering Research and Process Development Center, Institute of Microbial Technology, Sector 39A, Chardigard 160036, India.

Sambrook J, Russel D. (2001) Molecular cloning: a laboratory manual, $3^{\text {rd }}$ ed. Cold Spring Harbor, NY.

Secades, P and J. A. Guijarro. (1999) Purification and Characterization of Extracellular Protease from the Fish Pathogen Yersinia ruckeri and Effect of Culture Conditions on Production. IUBA, University de Oviedo. Spain.

Scopes, R.K. (1994) Protein Purification, Priciple and Practice. Third edition. SpringerVerlag. New York.

Sharmin, S., Md. Towhid Houssain and M.N. Anwar. 2005. Isolation and Characterization of Protease Producing Bacteria Bacillus amovivorus and Optimization of Some Factors of Culture Conditions for Protease Production. Dept of Microbiology, University of Chittagong-4331, Bangladesh.
Shafee, N.,S.N. Aris, R.N.Z. Abd Rahman, M. Basri, A.B.Shalleh. 2005. Optimization of Envronmental and Nutrisional Condition for the Production of Alkaline Protease by a Newly Isolated Bacterium Bacillus cereus strain 146. Dept of Microbiology, Dept of Biochemistry, Faculty of Biotechnology and Biomolecullar Sciences, Universiti Putra Malaysia.

Shumi, W., M.T. Hossain and M.N. Anwar, 2004. Proteolytic activity of a bacterial isolate Bacillus fastidiosus den Dooren de Jong. J. Biol. Sci., 4, 370-374.

Towatan,H, N., A. Painupong and P. Suntinanalert.1999. Purification and characterization of an extracellular protease from alkalophilic and thermophilic Bacillus sp. PS719. J. of Biosci and Bioeng, vol. 87 (5), 581-587.

Tian, B., J. Yang and K.Q. Zhang. 2007. Bacteria used in the biological control of plant-parasitic nematodes: populatioan, mechanisms of action, and future prospects. Review. FEMS Microbial. Ecol., 61, 197-213

Wilson, K. and J. Walker. (2005) Practical Biochemistry: Principles and Techniques. Fifth edition. Cambridge University Press. Cambridge.

Zhou, X.S., H.K. Kaya, K. Heungens, and G.B. Heidi., 2002. Response of Ants to Deterrent Factor(s) Produced by the Simbiotic Bacteria of Entomophatogenic Nematode. Appl. Environ. Microbiol., 68, 6202-6209.

Yang, J.K., I.L. Shih, Y.M. Tzeng and S.L. Wang. 2000. Production and purification of protease from a Bacillus subtilis that can deproteinize wastes. Enzyme and Microbial Tech, 26, 406-413 